\title{
THE EUROPEAN UNION'S COMMON AGRICULTURAL POLICY AND DEVELOPMENT OF AGRO-FOOD SECTOR IN GREECE
}

\author{
Ch. Paskhalidis ${ }^{1}$, D. Petropoulos ${ }^{1}$, \\ S. Sotiropoulos ${ }^{1}$, L. Papakonstantinou ${ }^{2}$ \\ ${ }^{1}$ Technological Educational Institute of Peloponnese \\ Kalamata, 24100, Greece \\ ${ }^{2}$ Agricultural University of Athens \\ Athens, 11855, Greece \\ chpaschal46@yahoo.gr
}

\begin{abstract}
The article analyzes the Common Agricultural Policy of the European Union (EU), reforms and consequences in agricultural sector of Greece. Since its inception, the Common Agricultural Policy has been the subject of many reforms that are being developed to meet the changing needs of society, market and competition of the European Union's (EU) rural economy with other alliances around the world. Of particular interest is the development of agricultural sector in Greece in the last 36 years, following its entry into the European Union. The contribution of agriculture (including agriculture, forestry and fisheries) in the Greek economy over the last 15 years has been significantly reduced. Data show a small trend in concentration of production and an increase in agricultural crop yield. There is an imbalance, which is reflected in large fluctuations in types of agricultural products. This applies to the volume of basic food production, which is governed by the economic policy of the European Union, expressed in product quotas and their production volumes. This leads to gradual decline in production, which is reflected in the need to meet domestic demand for plant and livestock foodstuffs, such as common wheat, legumes, sugar, lemons, more animal products and mainly meat. At the same time, imports of similar products from EU Member States are increasing, exacerbating the negative trade balance between the EU and the Republic of Greece. It is noted that the volume of subsidies in the EU remains at the same level, additional subsidies for farmers are gradually decreasing and the system of linking subsidies with production volume has been partially eliminated. The most effective support mechanisms for farmers will minimize the negative impact on the reduction of the overall financing in agricultural sector. The money saved as a result of reduction in subsidies will be spent on development of rural areas and improving effectiveness of structural policies. Also, comparative data are presented for other states of the European Union.
\end{abstract}

Key words: Greece, EU common agricultural policy, agro-food sector, European Agricultural Fund for rural development

\section{INTRODUCTION}

Creation of the Common Agricultural Policy (CAP) in the European Union (EU) Basic Principles and Objectives: The creation of the Common Agricultural Policy (CAP) is reflected in the Treaty of Rome, signed in 1957 by the six founding members of the European Economic Union (EEU) ) (France, Germany, Holland, Belgium, Luxembourg, Italy). In particular, Article 33 of the Treaty of the European Community (formerly Article 39 of the Treaty of the EEU), which includes the main objectives (CAP):

a) increasing agricultural productivity by developing technological progress, ensuring the rational development of agricultural production and the optimal use of resources, in particular labor force; 
b) ensuring a fair standard of living for rural population, in particular by increasing the individual earnings of agricultural workers;

c) stabilization of markets. Ensuring supplies;

d) ensuring reasonable prices in provision of goods to consumers.

The same article indicates that during CAP implementation it is necessary to consider:

a) the specific nature of agricultural activity as a result of the social structure of agriculture and structural and natural differences between different agricultural areas;

b) the need for gradual implementation of appropriate adjustments;

c) the fact that in the member states agriculture is a sector that is closely related to the entire economy $[1-5]$.

Article 34 of the European Union (EU) Treaty provides that achievement of the above objectives requires creation of a Single Market Organization (SMO). Depending on SMO products, it can take the form of general rules of competition, or the form of mandatory coordination of various national market organizations or the form of organization of the European market. Each SMO includes the whole range of measures necessary to achieve the objectives, in particular, price regulation, production support, marketing and other storage mechanisms and general mechanism for stabilizing imports and exports $[2,3]$.

The agro-food sector in the European Union affects the economy and, consequently, the society of its countries. The population increases with aging and decline of the rural population, due to the migration of rural youth into the cities where there is a strong urbanization phenomenon, with the result that many areas remain unused. The reasons for this phenomenon are low returns for farmers, lack of resources to cover the costs associated with agricultural production, quantity and quality of products. However, production has increased due to improved environments and technologies. Until 1992, agricultural spending represented $49 \%$ of the EU budget $[2,3,5,6]$.

In addition, the accession of new countries to the Union has a serious impact on the adopted policy. EU enlargement in 2004 augmented the number of farmers from 7 to 11 million, increased rural land by $30 \%$ and production by $10-20 \%$. New countries that joined in 2004 immediately got access to price support measures for export financing and intervention purchases. New countries have access to a rural development fund with a budget of 5 billion euros. The meaning of the Common Agricultural Policy (CAP) is to use market mechanisms in conjunction with government regulation [5]. The policy was based on the following principles: organization of agricultural market, establishment of uniform prices for most types of agricultural products, high degree of protection of internal agricultural market and price regulation, providing workers employed in the agricultural sector with a decent standard of living comparable to other economy sectors $[2,7]$.

A number of factors predetermined successful functioning of the CAP until the end of the 70s. The most important result is that the Community has achieved self-sufficiency in agricultural products. The CAP largely reflects the EU's leading role in global food production and trade in agricultural products. Today, the EU accounts for $17 \%$ of world food exports; The EU is ranked second as a global exporter of dairy products and pork 
and third place as an exporter of poultry and grain. According to the FAO, in 2013 the European Union exported agricultural products worth 151.2 trillion dollars [4].

The original goals of the European Community have already been achieved. A single domestic market for agricultural products has been created, self-sufficiency has been achieved. However, agrarian policy had significant drawbacks. If at first the CAP was based on fairly rigid mechanisms, then in the new conditions these mechanisms and especially amount of financial resources and their distribution needed to be revised [1, 7-9]. Thus, in order to improve the unified agrarian policy, a series of reforms were carried out: the first reform - 1984, the second - 1992, the third - the end of the 90s, the fourth in 2003 and the last reform of the CAP - in 2013. Within its framework, the following tasks were set: Implementing single payments to farmers, regardless of production, but observing environmental standards and ensuring food safety, strengthening policies for rural development, reducing direct payments to large farms and creating the European Agricultural Fund for Rural Development (EAFRD) and the European Agricultural Guarantee Fund (EAGF) in accordance with the regulations on financing of the CAP on June 21, 2005 [10]. It was proposed to change the principle of issuing subsidies, which made it possible to optimize the pan-European agro-budget in connection with entry of new countries into the EU. Creating a common domestic market without any trade barriers should provide new opportunities for rural producers. In general, the reform is aimed at organizing agriculture in the European space that would satisfy market and consumers requirements [2].

The gradual redirection of funds from subsidies to environmental protection measures should lead to elimination of crisis of overproduction of agricultural products and the excessive use of natural resources due to the use of chemicals and fertilizers [2]. The idea of reforming the CAP is also to move from a "productive" agrarian policy model to a more environmentally friendly and based on qualitative criteria. Therefore, a system of single direct payments is introduced, depending on environment preservation and safety of products, humane attitude to animals, and increase in employment. It was planned that volume of subsidies in the EU will remain at 42 billion euros, and their annual growth should not exceed $1 \%$, offsetting the effect of inflation. Additional payments for farmers have gradually been reduced (by $3 \%$ in $2005,4 \%-2006$, and further by $5 \%$ per year) [7].

The European Union pursues two goals: first, to reduce the budget expenditures on the CAP and increase the costs of other areas (in particular, scientific research); secondly, because of agriculture, negotiations in the WTO, which deal with a much wider range of problems, do not complicate.

Thus, the main conclusions in the evaluation of the EU agrarian policy are: the multiplicity and ambiguity of agricultural programs carried out within framework of the EU agrarian policy, the complicated process of obtaining subsidized funds leads to the development of bureaucracy and does not contribute to the growth of competitiveness among agricultural producers. The CAP has already come a long way of becoming in the 20th century, and now it has the opportunity to truly become the European agricultural model of the 21 st century [7]. It is worth emphasizing that since 2014, the EU has been implementing a new phase of the common agrarian policy, the main priorities 
of which are: improving the competitiveness of agriculture: sustainable management of natural resources, as well as combating climate change; achieving a balanced territorial development of the rural economy, creating and maintaining employment. The specified priorities of general agrarian policy for the program period 2014-2020 reflect the continuity of previously identified priorities.

In essence, the MFS illustrates EU policy priorities in various areas of funding. The costs will be directed to financing Pillar 1 (CAP) for the period 2014-2020 and amount to current prices of 317.2 billion euros, while Pillar II will require a total of 101.2 billion euros. About 17.1 billion euros will be added to these year expenditures, not provided in the MFS, which will increase the total budget for agriculture $2014-2020$ to 435.6 billion euros. The resources that the CAP ultimately absorbs account for $37.7 \%$ of the total EU budget, which is reduced in comparison with the period 2007-2013, which was $41.7 \%$. The multi-year financial structure (MFS) defines the resources for financing European policy, including the CAP, as a rule, for the next seven years. Therefore, the MFS illustrates the EU's policy priorities in various areas of funding. It is noted that the development of the European Union (EU) economy will begin to progress but will remain below $2 \%$ per year. After several years of decline in euro price, its currency ratio is considered to be formed at the level of 1.37 dollars per euro in 2024 [10].

The Common Agricultural Policy (CAP) from its inception to date has been the subject of many ongoing reforms, developed to meet changing needs of society, market and competition of the rural economy of the European Union (EU) with other alliances around the world. More radical reforms are considered to be Ray Mac Sharry in 1992 and CAP in 2003, which established direct payments to producers established independently of production and type of agricultural products [1, 7].

The general trend shows that CAP development and reforms have a protective character and interventionism, which characterizes it, gives way to a more liberal model. It should be noted that these goals have not been replaced and not changed by the successive reforms of the original Treaty and are an important and integral part of the Treaties to date.

For Greece, we should not follow the example of rich European countries that can afford to keep inefficient agriculture through market price support measures. Financial resources must be invested in know-how, modern technology, management skills and infrastructure that Greek agriculture needs in order to become competitive. The greatest attention should be paid to consulting services, village infrastructure, as well as measures aimed at preserving the environment $[1,2,7,8]$.

\section{MATERIALS AND METHODS}

The main indicators of agricultural sector of the Republic of Greece: Agricultural land in Greece accounts for $31 \%$ of the total area of the country, which is 517.8 thousand hectares [11-14]. Approximately $71 \%$ of this area (367.4 thousand hectares) is located in mountainous or foothill area, and its size has remained stable for many years with a slight upward trend [13].

According to the Ministry of Rural Development and Products, $54.6 \%$ of the total agricultural land was used for tilled crops, $2.8 \%$ for melon and vegetable crops, $32 \%$ for 
permanent garden fruit plantations and only 10.6\% remain unprocessed in 2014 [14, 15]. The average land size of one farmer in the country still remains very small. According to statistics, in 2014 it amounted to 4.77 hectares per farm, which is slightly higher compared to the beginning of the 90s. Studying data from other EU countries we see that corresponding average land size of a farmer is 22.0 hectares. On average, one Greek farmer accounts for an area that is four times smaller than the area occupied by farmers from small EU countries. It is characteristic that the average size of agricultural farm in Greece remained practically unchanged from 1990 to 2014, whereas in European countries with high agricultural production and employment of a significant part of population in the agricultural sector (Portugal, Italy and Bulgaria) the area per farmer during this period increased significantly. It should be noted that Greece is one of the few EU countries with a high percentage of fruit trees from the total arable land. In total agricultural production $19 \%$ are vegetables, followed by fruit $18.5 \%$, animal husbandry $14.5 \%$, animal products, milk, butter $-14 \%$ grains and olive oil $-8 \%$ [13]. The total value of agricultural products in Greece is 9.7 billion US dollars. Of this amount, $69 \%$ is accounted for by the production of plant products [15]. Therefore, production of plant products occupies a dominant position in the rural economy of the country.

In terms of value, agricultural production in Greece has not changed from 2010 to date. However, in comparison with the EU statistics, it decreased from 2.91 to $2.5 \%$.

According to 2007 data the number of agricultural farms is about 854.1 thousand [12]. The number of farms decreased by 100 thousand in the period 1987-1990, which was a consequence of the economic policy of the European Union by subsidizing large farms. A significant part of small farms could not receive subsidies, since their products were intended primarily for personal consumption and did not create a surplus in the sales market being an unofficial income for citizens living in urban and semi-urban areas. A high number of farms are associated with the division of property and possession between members of the same family in order to avoid taxation or to receive subsidies. Despite the survival of a very small number of agricultural farms (up to 2 hectares in area), there is a steady trend of land concentration in larger farms. It is expressed for categories of farms with agricultural land within an area of 30 to 100 hectares, and there is also a slight increase in the percentage of farms with a total area of up to 20 hectares. Thus, the number of farms up to 20 hectares in 1990 accounted for $97.43 \%$ of all farms and occupied $76.30 \%$ of the total land area, and in $2014-95.66 \%$ of the total number of farms, which amounted to $64.35 \%$ of the total land area in the country. Of particular interest is the development of farms based on the form of ownership. The state maintains a form of transfer of agricultural land for hire to third parties. This trend is obvious, since in 2014 it accounted for almost 32\% of the total amount of land used for agriculture, which is $10 \%$ higher than the 1990 figures $[12,13]$.

The main statistical indicator for studying changes in the structure of farms is the annual standard gross margin. It should be clarified that this indicator is not an indicator of the profitability of the farm, as it includes work of farmer and his family members, someone else's labor employed by the farmer (variable capital), but also part of the fixed capital [13]. 
Thus, the annual standard gross margin as an indicator allows to evaluate some general trends, since it is not comparable between different types of farms. For example, with regard to the cultivation of cotton, a farm of 10 hectares gives about 45,000 euros and a net income of 5,000 euros, while growing wheat on the area of 40 hectares, the same 45,000 euros, and a net profit of 12,000 euros. According to the above, in the first case the net profit amounted to 500 euros, and in the second only 300 euros per hectare. It has been established that a farm with an annual standard gross margin of less than 48,000 euros cannot even ensure its simple sustenance [12].

As for livestock, more than $43 \%$ of the livestock (in 2007 total number of farms amounted to 860.2 thousand) belongs to 371.2 thousand farms. Livestock remains with minor fluctuations at sustainable levels, which indicates its lack of development and relative stabilization. There is a significant reduction in the number of livestock farms, as evidenced by data confirming a decrease in the number of farms from 475.6 thousand livestock farms in 1990 to 371.2 in 2007 , which is $23 \%$ less.

Based on the available data on the state of livestock sector, the following conclusions can be made:

1) presence of a highly time-stable number of small livestock farms, which account for at least $10 \%$ of the total livestock;

2) strengthening trends in the concentration of livestock in larger farms, where 2.4 thousand livestock farms control $22 \%$ of the total livestock population;

3 ) products used as animal feed and cost of its production in Greece are among the highest in the EU with an increase from $63.6 \%$ in 2010 to $76.7 \%$ in $2014[12,13]$;

4) gross domestic meat production decreased from 572.0 thousand tons in 1981 to 491.0 tons in 2010. In the same period, there was an increase in meat consumption from $70.0 \mathrm{~kg}$ in 1981 to $83.0 \mathrm{~kg}$ in 2010 . This growth was fully covered by imports, so the degree of self-sufficiency in meat declined from $84 \%$ to $50 \%$ over the same period $[12,16]$. There is a very limited degree of self-sufficiency in beef, $57 \%$ in 1981 and $24 \%$ in 2010 and relatively high availability of lamb meat $-87 \%$ and poultry meat $-79 \%$ in $2010[3,6,8]$.

Data on employment, total employment of hired labor and self-employment in rural farms show a clear downward trend in employment in agricultural production as a whole [11-13].

The participation of the agricultural sector (which includes agriculture, forestry and fisheries) in the Greek economy has declined significantly over the past 15 years. The contribution of gross value added (GVA) of agrarian sector to the total GVA of the country in 2014 was $4.3 \%$ from $6.1 \%$ in 2000 and $8.8 \%$ in 1995 . The above figures should also include contribution of processing industry of food, beverages and tobacco, which accounts for almost $3.0 \%$ of the total gross value added (GVA), while it accounts for $31 \%$ of the total processing industry [10].

The agro-food sector (agricultural sector and food, beverage and tobacco processing industry) contributed $7.2 \%$ of the total gross value added (GVA) in 2014, compared with $9.1 \%$ in 2000 and $11.8 \%$ in 1995 . Moreover, it accounts for $15 \%$ of the total employment in Greece [10]. In addition, over the past decade, agricultural income in Greece has decreased on average by $0.4 \%$ per year compared with a growth of $1.6 \%$ in the Eurozone countries. 
Since 2007 (EAP) has invested more than 19.53 billion Euros in agriculture and rural areas of Greece in total costs for direct payments, market and development measures for rural areas. Most of the funds sent to Greece for the period 2008 - 2013 from the CAP, particularly direct payments $(77.7 \%)$, were higher by $10 \%$ on average in the EU (68\%). By 2013, share of the CAP should have been (32\%). On the contrary, the share of expenditures on the Regional Policy in 1988 amounted to $17 \%$ of the EU budget, $46.7 \%$ of the EU budget was spent on it, 49.8 billion euros in 2006 (more than 48.5 billion euros in 2005), and it was planned to increase to $36 \%$ in 2013 .

In particular, $12.5 \%$ of total employment and $2.7 \%$ in food, beverage and tobacco processing industry work in the agricultural sector. Between 2000 and 2014, the number of people employed in the agricultural sector decreased by $29 \%$, while the number of people working in the food, beverage and tobacco processing sector increased by $8 \%$. The trade balance of Greek goods in agro-food sector is negative [16]. Almost 69\% of exports went to the countries of the European Union (EU), and $80 \%$ of imports of this category of goods - from EU countries [10]. The largest category of exports of agricultural products in 2012 - 2014 for fruit and vegetables amounted 34\%, followed by fish $-10.8 \%$, dairy products $-7.9 \%$, vegetable fats and oils $-7.8 \%$, tobacco $-7.6 \%$, and cotton - 7.1\% [10]. The most important products that are of high quality (high competitiveness at high prices) are: olive oil, olives, pickles, raisins, canned vegetables, tobacco, tomato paste, yogurt, rice, sheep and goat skins, cotton seed oil and bakery products. Lower prices are the main comparative advantage of such highly competitive products as fruit, cotton, sheep cheese, wine and so on. In the case of imports of this category, the largest percentage relates to livestock products - $17 \%$, followed by dairy products - 13\%, fruit and vegetables - 10\%, grain and feed concentrates $9 \%$ [16]. Agricultural products are the third largest category of exported products, accounting for 5.2 billion euros in 2014, or 19\% of total exports, representing 14\% of imports [10]. Vegetables and horticultural products account for the largest share of exports. The trade balance of agro-food products is negative. The decline in imports that began in the last 5 years due to the economic crisis, combined with good export performance of agricultural products, led to a reduction in the deficit, which in 2014 was limited to 1.36 billion euros. Most individual product categories have a deficit balance, with the exception of fruit and vegetables, fish, tobacco, cotton, vegetable oils and fats, which have a positive balance.

\section{RESULTS AND DISCUSSION}

If we consider contribution of agriculture to the EU and Greece gross value added of the agricultural sector in Greece amounted to 3.3\% of GDP in 2014, compared with $1.4 \%$ in the EU. For the period 2012 - 2014 Greece brought $3.0 \%$ of gross value added in the EU agricultural sector and the countries with the highest participation were Italy 16.0\%, France - 15.9\%, Spain - 12.2\%, Germany - 10.4\%, United Kingdom - 6.0\%, the Netherlands $-5.5 \%$. The value added obtained in agricultural production lags behind key competitors. From the distribution of value added along the agro-food chain, it seems that for every 1 euro, the value of primary products in processing sector of food and beverages adds value of 0.4 euros in our country, when in Spain and Italy this amount is 1.5 euros. 
In the period 2004-2014 agricultural income in Greece decreased by an average of $0.4 \%$ per year, while in the EU it increased by $3.4 \%$ and in the Eurozone countries by $1.6 \%$. Gross fixed investment in the agricultural sector in Greece as a percentage of the gross value added of the agricultural sector is more than $10 \%$ lower than the EU average, reflecting a reduction in investment in the agricultural sector and consequently, inability to modernize farming management methods.

In 2014-2020 the Common Agricultural Policy of the European Union will invest in Greece more than 19.5 billion euros in agriculture and rural areas. The budget for direct payments in Greece is about 15.4 billion euros. Thirty percent of direct payments will be associated with three environmentally friendly farming methods: crop diversification, continuous pasture conservation, and $5 \%$ will be channeled towards environmental interest preservation or measures that are thought to have equivalent environmental benefits. Greece will allocate more than 4.2 billion euros to measures in favor of rural areas in accordance with the priorities outlined in the rural development program $[10,15]$.

\section{CONCLUSIONS}

In the development process of agricultural sector, its structure, applied technology, level of farmer experience, and classical factors of production, such as science, politics, financing, market, etc., play a decisive role.

In this process, the key point is the accession of Greece in 1957 to the European Economic Union. The current structure and organization of Greek agriculture and the composition of its primary production reflect the influence of both the country's national policy and the Common Agricultural Policy of the European Union (EU) before and after Greece joined the EU. The total area of agricultural land remains stable compared to the 1980s. The average size of farms in Greece remains very small. Many small farms remain without economic activity in order to receive subsidies. The number of farms with small areas of agricultural land (up to $2.0 \mathrm{ha}$ ) is increasing. There is a steady trend of land concentration in larger farms. The number of farms decreased in the period 1987 to 1990, which was a consequence of the economic policy of the European Union subsidizing large farms. $12.5 \%$ of the total employment are in agricultural sector and $2.7 \%$ in processing industry of food, beverages and tobacco. Between 2000 and 2014, the number of people employed in the agricultural sector decreased by $29 \%$, while the number of people working in the food, beverage and tobacco processing sector increased by $8 \%$. In the total agricultural output, vegetables make up the largest part and followed by fruits and livestock, animal products, milk, butter, cereals, and olive oil. The total value of agricultural products in Greece is 9.7 billion US dollars. In terms of value, agricultural production in Greece has not changed from 2010 to date. However, comparing the percentage with that of the EU, it has decreased from 2.91 to $2.5 \%$. $69 \%$ of this amount is for production of plant products, which occupies a dominant position in the rural economy of the country. In 2014, the gross value added of the agricultural sector in Greece amounted to $3.3 \%$ of GDP, compared with $1.4 \%$ in the EU. The agro-food sector in 2014 amounted to $7.2 \%$ of the total gross value added (GVA), compared with $11.8 \%$ in 1995 . For the period 2012 - 2014 Greece brought $3.0 \%$ of gross 
value added in the EU agricultural sector. The trade balance of Greek agro-food products is negative and is the third largest category of exported products, accounting for $19 \%$ of total exports and $14 \%$ of imports. Almost $69 \%$ of exports are directed to the countries of the European Union (EU), and $80 \%$ of imports of this category of goods are from EU countries. Gross investment in fixed assets in the agricultural sector of Greece as a percentage of the gross value added of the agricultural sector is just above $10 \%$, lower than the EU average, reflecting a reduction in investment in the agricultural sector and consequently, inability to modernize farm management practices. The figures given in this study show that impact of the Common Agricultural Policy of the European Union on economy of agricultural sector in Greece was insignificant.

\section{REFERENCES}

1. Maravégias N. I diadikasía tis Evropaikís olklírosis kai i ellinikí georgía sti dekaetía tou 90. Athína: ekdPapazisi; 1992. (In Greek).

2. Rousianoú Aik. Koini agrotikí politikí kai agrotikí anáptyxi stin Elláda. Diplomatikí ergasía Panepistimio Patron; 2015. (In Greek).

3. Roúfos CH. Enallaktikés stratigikés anáptyxis tou georgikoú toméa stin Elláda. Metaptychiakí Diatriví. Panepistímio Makedonías; 2011. (In Greek).

4. Kormishkina LA, Semenova NN, Kormishkin ED. Problem of food security and agricultural development in the XXI century in Europe. An Agrarian Science of Euro-North-East. 2017; (1):74-78. (In Russ).

5. Nazarenko VI. Forms and directions of state support for agriculture in the West. Economy of agricultural and processing enterprises. 2007; (3):10-13. (In Russ).

6. European Commission - Eurostat: Farm Structure - Historical Results — Surveys from 1966/67 to 1997. Eurostat; 2010.

7. Pézaros P. I koiní Agrotikí Politikí Exélixi kai Prooptikés. 2011. (In Greek).

8. Pezaros P. The Agenda 2000: CAP reform agreement in the light of the future EU enlargement. European Institute of Public Administration; 1999.

9. Tzakósta A. I Néa Koiní Agrotikí Politikí stin Elláda Efarmogi kai epiptóseis. 2010. (In Greek).

10. Lekkos I, Leventákis A. I symvolí kai prooptikés tou agrotrofikoú toméa stin Elláda. Meléti tis Trápeza Peiraió; 2015. (In Greek).

11. Benatos G. The agricultural sector in Greece (meaning - problems - perspective). Athens; 2007. (In Greek).

12. Kadíti E, Nítsi E. O Agrotikós Toméas stin Elláda Ekthéseis. 60 Kentro Programmatismoú kai Oikonomikón Erevnón. Athína; 2010. (In Greek).

13. Paskhalidis C, Petropoulos D, Sotiropoulos S, Zamanidis P, Chamurliev GO, Papakonstantinou L. The main trends of Greece agricultural policy. Mezhdunarodnaya nauchno-prakticheskaya konferentsiya. Volgograd: VGAU Publ; 2018. (In Russ).

14. Savvas D. Development of plant production in Greece. Athens; 2014. (In Greek).

15. Ellinikí Dimokratía Ypourgeío Anáptyxis kai Trofímon. 'Protáseis tis Evropaikís Epitropís gia tin Koiní Agrotikí Politikí me orízonta to 2014-2020. 2011. (In Greek).

16. Petrópoulos D. I diéyrynsi tis Evropaikis Enosis kai i thési tou agrotikoú toméa tis Elládas. Epitheorisi Oikonomikón Epistimón TEI Ipeirou, Tefchos 11. 2007. (In Greek).

\section{INFORMATION ABOUT AUTHORS}

Christos Paskhalidis - Candidate of Agricultural Sciences, Professor, Technological Educational Institute of Peloponnese, e-mail: chpaschal46@yahoo.gr

Dimitrios Petropoulos - Candidate of Economic Sciences, Associate Professor, Technological Educational Institute of Peloponnese, e-mail: dpetro@teikal.gr 
Stauros Sotiropoulos - Senior Lecturer, School of Agriculture, Technological Educational Institute of Peloponnese, e-mail: ssotiropoulos@gmail.com

Loukas Papakonstantinou - Research Officer, Agronomist, Agricultural University of Athens, e-mail: LoukPapak@gmail.com

\title{
For citation:
}

Paskhalidis C, Petropoulos D, Sotiropoulos S, Papakonstantinou L. The European Union's common agricultural policy and development of agro-food sector of Greece. RUDN Journal of Agronomy and Animal Industries, 2018, 13 (4), 373-382. doi: 10.22363/2312-797X-2018-13-4-373-382.

DOI: 10.22363/2312-797X-2018-13-4-373-382

\section{ЕДИНАЯ АГРАРНАЯ ПОЛИТИКА ЕВРОПЕЙСКОГО СОЮЗА И РАЗВИТИЕ АГРОПРОДОВОЛЬСТВЕННОЙ ОТРАСЛИ ГРЕЦИИ}

\author{
Ch. Paskhalidis ${ }^{1}$, D. Petropoulos ${ }^{1}$, \\ S. Sotiropoulos ${ }^{1}$, L. Papakonstantinou ${ }^{2}$ \\ ${ }^{1}$ Technological Educational Institute of Peloponnese \\ Kalamata, 24100, Greece \\ ${ }^{2}$ Agricultural University of Athens \\ Athens, 11855, Greece \\ chpascha146@yahoo.gr
}

Анализируется единая аграрная политика Европейского Союза (ЕС), реформы и ее последствия для агропродовольственного сектора Греции. Единая аграрная политика (ЕАП) с момента ее создания до сегодняшнего дня была предметом многих проводимых реформ, развивалась для удовлетворения меняющихся потребностей общества, рынка и конкуренции сельской экономики Европейского Союза (ЕС) с другими альянсами по всему миру. Особый интерес представляет развитие агропродовольственного сектора в Греции за последние 36 лет, после ее вступления в Европейский Союз Участие сельского хозяйства (включая сельское, лесное хозяйство и рыболовство) в греческой экономике за последние 15 лет значительно сократилось. Данные свидетельствуют о небольшой тенденции по концентрации производства и увеличении урожайности сельхоз культур. Отмечен дисбаланс, который выражается в больших колебаниях по видам сельскохозяйственной продукции. Это касается объема производства основных продуктов питания, который регулируется экономической политикой Европейского Союза, выраженной в квотировании видов продукции и объемов их производства. Это постепенно приводит к снижению объемов производства, что отражается в необходимости обеспечения внутреннего спроса на продукты питания растениеводства и животноводства, такие как мягкая пшеница, бобовые, сахар, лимоны, большинство продуктов животноводства и особенно мяса. В то же время растет импорт аналогичных видов продукции из стран - членов ЕС, что усиливает отрицательное сальдо торгового баланса между ЕС и Республикой Грецией.

Отмечается, что объемы субсидий в ЕС сохраняются на прежнем уровне, доплаты для фермеров постепенно сокращаются, частично ликвидирована система привязки субсидий к объемам производства. Более эффективные механизмы поддержки фермеров позволят минимизировать негативные последствия для сокращения общего финансирования аграрного сектора. Сэкономленные в результате сокращения субсидий деньги пойдут на развитие сельских территорий и повышение эффективности структурной политики. Также приведены сравнительные данные по другим государствам Европейского Союза.

Ключевые слова: Греция, Единая аграрная политика ЕС, агропродовольственный сектор, европейский сельскохозяйственный фонд для развития села 